\title{
11 Distinguished church leader essay
}

\author{
Aladura theology - the case of the \\ Church of the Lord (Prayer \\ Fellowship) Worldwide
}

\author{
Rufus Okikiola Ositelu
}

\section{Introduction}

The theology of the Church of the Lord (Prayer Fellowship) Worldwide (a.k.a. Aladura) is based on the Scriptures, natural law, and Divine Revelation - 'The LORD says', as interpreted authoritatively by the Supreme Council of Prelates (SCP), which is also known as the Council of Bishops. The Church of the Lord's (Prayer Fellowship) Worldwide (TCLPFW) is manifested in its six tenets.

\section{The tenets of the Church of the Lord (Prayer Fellowship) Worldwide}

TCLPFW is conscious of its mission to spread the good news of our Lord Jesus Christ to every nook and corner of the world. The cross of Christ Jesus is our guide. TCLPFW is a revealed covenant church from above. The solid foundation of the church is laid on love, faith and hope. Every adherent of the church is enjoined to abide and practise these virtues.

The six tenets of the church can be described as:

1 Pentecostal in power;

2 biblical in pattern;

3 evangelical in mission;

4 prophetic in ministry;

5 social in responsibility; and

6 ecumenical in outlook.

\section{Brief introduction of Aladura tenets}

Biblical in pattern in the sense that in all matters of faith, conduct, doctrine, rituals, character and discussions, our supreme court of appeal is the Holy Bible. Thus, the Holy Bible is our spiritual constitution.

Pentecostal in power in the sense that the Spirit of our Lord Jesus Christ is the administrator of the church through which the church is guided, directed, 


\section{Rufus Okikiola Ositelu}

filled, influenced, administered and managed. Our power of attorney is: 'In Jesus's name'.

Evangelical in mission in the sense that we carry the Gospel to the nooks and corners of the world, and we preach the good news to all, irrespective of background, race or gender. Matthew says:

Therefore, go and make disciple of all nations, baptizing them in the name of the Father and of the Son and of the Holy Spirit, and teaching them to obey everything I have commanded you. And surely I am with you always to the very end of age.

Prophetic in ministry in the sense that God endowed the founder of the church and promised to endow all that will follow him with prophetic virtue for the benefit of mankind. This is the genesis and the pillar on which TCLPFW is anchored. The gifts of prophecy, dream, vision, revelation, speaking in tongues, healing, signs and wonder, teaching and administration, and so on are bestowed on the church. On outpouring of the Spirit, the Lord said in Joel:

And afterward, I will pour out my Spirit on all people. Your sons and daughters will prophesy, your old men will dream dreams, your young men will see visions. Even on my servants, both men and women, I will pour out my spirit in those days.

Social in responsibility in the sense that the church believes it should be a blessing to the community where the church is situated and the inhabitants of the state in general. We therefore endeavour to provide social amenities through the NGO of the church - the Justice, Equity, Peace and Empowerment Foundation (JEPEF).

Ecumenical in outlook in the sense that we embrace and encourage brotherly and sisterly love among the believers, and we do not forsake the saints, for the prayer of the High Priest - our Lord Jesus Christ - for the church is, 'That they may be one' (John 17:21). We believe in 'unity in diversity' and share in fellowship, unity in the bond of peace with all believers who worship and serve Jesus Christ as Lord, Saviour and Redeemer. We are told that:

The body is a unit, though it is made up of many parts; and though its parts are many, they form one body. So it is with Christ. For we were all baptized by one Spirit into one body - whether Jews or Greeks, slave or free - and we were all given the one Spirit to drink.

And our Lord Christ Jesus in John said: 
My prayer is not for them alone, I pray also for those who will believe in me through their message, that all of them may be one, Father, just as you are in me and I am in you. May they also be in us so that the world may believe that you have sent me.

\section{Sacraments and festivals}

Formal Aladura worship is ordered by means of the liturgy, which is regulated by the authority of the church. The Aladura Church celebrates all the major Christian sacraments and festivals, including baptism by immersion, confirmation, holy communion, penance, reconciliation, anointing, holy orders, observation of Easter and Christmas seasons. Aladura believes that man comes from God and will eventually go back to God. 'For it is appointed for men to die once, but after this judgment' (Hebrews 9:27).

\section{Apostles' Creed}

We believe in the Apostles' Creed (Nicene Creed), and it is thus recited every Sunday as a form of reminder during the Worship Service. We believe in the African tradition and thus feel free to practise Christianity within our cultural context as long as such practice agrees with the teachings of the Holy Bible. According to 2. Corinthians 3:17; we are told: 'Now the Lord is the Spirit; and where the Spirit of the Lord is, there is liberty'.

\section{The Holy Trinity}

We believe in the triune God (the Holy Trinity) - God the Father, Son and Holy Spirit - the God-Head, one God in essence, but three personalities - the Father decrees, the Son carries out the instruction, through the power of the Holy Spirit (Matthew 29:19).

\section{Salvation (soteriology)}

We believe that salvation comes through Jesus Christ alone. Jesus Christ is the Saviour of humankind (John 1:29). In fact, the whole sacrificial system established by God in the Old Testament set the stage for the coming of Jesus Christ, who is the perfect sacrifice God would provide as atonement for the sins of His people (Romans 8:3; Hebrews 10). The sacrifice of lambs played a very important role in the Jewish religious life and sacrificial system. When John the Baptist referred to Jesus as the 'Lamb of God who takes away the sin of the world' (John 1:29):

For the grace of God that brings salvation hath appeared to all men, Teaching us that, denying ungodliness and worldly lusts, we should live soberly, 
righteously, and godly, in this present world; Looking for that blessed hope, and the glorious appearing of the great God and our Saviour Jesus Christ; Who gave himself for us, that he might redeem us from all iniquity, and purify unto himself a peculiar people, zealous of good works.

(Titus 2:11-14)

\section{Ten Commandments}

We believe in the Ten Commandments and the commandments of Jesus Christ (2. Timothy 3:16; 1. Timothy 1:8; Exodus 20:1-17; Deuteronomy 5:1-21; Matthew 5:17-19; 22:37-40; Romans 3:31; Mark 12:28-34).

\section{Priesthood of All Believers}

We believe in the ordination of men and women as priests for the work of God in the Vineyard (ministry). 'But ye are a chosen generation, a royal priesthood, an holy nation, a peculiar people; that you may proclaim the praises of Him who called you out of darkness into His marvellous light; his marvellous light' (1. Peter 2:9). The primate, cardinals, archbishops and bishops are all members of the SCP, with special responsibilities as stated in the constitution of the church, including the church provinces, dioceses, aones and the local church overseers.

\section{Succession}

The succession of the primate (the administrative and spiritual leader of the church) is regulated in the constitution of the church. The incumbent primate may proclaim his successor as directed by the Holy Spirit. In the absence of any proclamation, and after the demise of the primate, the board of trustees of the church will summon the SCP to the Holy Mount Tabieorar to fast and pray for seven days during which they will inquire of the Lord God who should be the next primate (Exodus 18:15; 1. King 22:5, 7; 2. Chronicles 18:6; Genesis 25:22; Judges 18:5; Acts 6:3-6).

\section{Contemporary issues}

Every religion has always been practised within the cultural context of its believers. For no religion ever existed in a cultural vacuum - Hinduism, Jainism, Buddhism, Confucianism, Taoism, Shintoism, Zoroastrianism, Judaism, Christianity, Islam, etc., they all came into being in a cultural existence. African Initiated Churches, therefore, should feel free to practise Christianity within their cultural context as long as such practice agrees with the teachings of the Scriptures (2. Corinthians 3:17). They are therefore not apologetic of having a culture which respects the elders and accords much more respect to a Supreme Being (Creator). Christian ethics recognise the cultural differences and do not demand that one gives up his/her own culture in order to keep God's commands. The Christian ethic is anchored ultimately and firmly in the unchanging nature of a 
God of perfect love and justice. The Christian view of ethics has a superior source (God), a superior manifestation (Jesus Christ), as well as a superior declaration (Holy Bible), and superior motivation (the love of Christ Jesus).

\section{Practices and observances}

1 Efficacy of prayer and fasting - TCLPFW believes in the efficacy of prayer and fasting (Matthew 17:21; Mark 9:29). Jesus Christ said: 'So He said to them, "This kind can come out by nothing but prayer and fasting"' (Mark 9:29; NKJV).

2 Mode of worship - TCLPFW and other African Initiated Churches have changed the mode of Christian worship, observances and practices dramatically in Nigeria, Africa and other parts of the world.

3 Recognition of lack of life in Mission Churches - a commentary in one of the publications of the Christian Council of Nigeria (CCN) in the year 1960 about the Aladura Churches: 'The Aladura Church movement had risen out of dissatisfaction with the life of the Mission Churches (or its lack of life)'. This recognition and adoption of the Aladura practices by the European/American mission is visible in Africa and other parts of world.

4 Pacesetters in using local lyrics - the African Initiated Churches are pacesetters in the use of local lyrics during worship services.

5 Ordination of women-TCLPFW is the pacesetter in the ordination of women. The church believes in the Royal Priesthood of all believers. 1. Peter 2:9; says: 'But you are a chosen generation, a royal priesthood, a holy nation, His own special people, that you may proclaim the praises of Him who called you out of darkness into His marvelous light' (1. Peter 2:9; NKJV).

6 Speaking in tongues - speaking in tongues is a gift of the Holy Spirit, which God has immeasurably endowed on the African Initiated Churches. As a matter of fact, some Christians of other denominations and Christian families are afraid to attend the worship service of the Aladura Churches as their past, present and future may be exposed by the Holy Spirit. Paul the Apostle told the Corinthians and in extension all Christians: 'Therefore, brethren, desire earnestly to prophesy, and do not forbid to speak with (in) tongues' (1. Corinthians 14:39).

7 Prophecy - is a gift from the Holy Spirit and it is the foundation and one of the tenets of TCLPFW. We are told in 1. Corinthians 14:24-25:

But if all prophesy, and an unbeliever or an uninformed person comes in, he is convinced by all, he is convicted by all. And thus the secrets of his heart are revealed; and so, falling down on his face, he will worship God and report that God is truly among you.

(1. Corinthians 14:24-25; NKJV)

We are therefore to: 'Pursue love, and desire spiritual gifts, but especially that you may prophesy' (1. Corinthians 14:1; NKJV). 
8 Respect for the Lord God and removal of shoes in the temple - the white garment (a.k.a. Aladura) church members remove their shoes when about to step into the Temple of God. They do this out of the African tradition of respect for elders and people in authority and moreover as a sign of reverence for the Supreme Being (the Lord God Almighty).

9 White garment - white is the symbol of purity and righteousness. For TCLPFW, the wearing of white garment serves as a reminder to our members and followers that we should be holy for our heavenly Father is holy. 'And you shall be holy to Me, for I the Lord am holy, and have separated you from the peoples, that you should be Mine' (Leviticus 20:26; NKJV). '[B]ecause it is written, "Be holy, for I am holy"' (1. Peter 1:16; NKJV). The white garment also serves as a 'leveller', thus freeing individuals from the worry of 'What am I going to wear to church? What will people think about me if they see me wearing the same clothing or hat which I wore last week?' These types of worries do not exist in the Aladura Churches.

10 Extempore (impromptu) prayers - African Initiated Churches are pacesetters in extempore (impromptu) prayers, compared to read prayers in the Mission Churches.

\section{Bibliography}

Ositelu, Rufus. 2000a. Leadership. Ogere: TCLAW Publications.

Ositelu, Rufus. 2000b. Practices and Observances of the Church of the Lord (Aladura) in the Light of the Old and New Testaments. Ogere: TCLAW Publications.

Ositelu, Rufus. 2002. African Instituted Churches: Diversities, Growth, Gifts, Spirituality and Ecumenical Understanding of African Initiated Churches. Hamburg: LIT.

Ositelu, Rufus. 2016. CHRISTIANITY: Inside Story from an African Perspective. Ogere: TCLAW Publications. 